Int. J. Electrochem. Sci., 13 (2018) $7385-7396$

International Journal of

ELECTROCHEMICAL

SCIENCE

www.electrochemsci.org

\title{
Synthesis, Characterization and Application of Ferrochrome slag/polyaniline Nanocomposite as Corrosion Protection Coatings for Carbon Steel
}

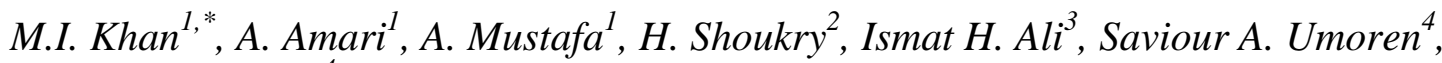 \\ A. Madhan Kumar ${ }^{4}$ \\ ${ }^{1}$ Chemical Engineering Department, College of Engineering, King Khalid University, Abha, Saudi \\ Arabia, \\ ${ }^{2}$ Physics Department, College of Science, King Khalid University, Abha, Saudi Arabia \\ ${ }^{3}$ Chemistry Department, College of Science, King Khalid University, Abha, Saudi Arabia \\ ${ }^{4}$ Center of Research Excellence in Corrosion, Research Institute, King Fahd University of Petroleum \\ and Minerals, Dhahran 31261, Saudi Arabia \\ *E-mail: $\underline{\text { mkaan@kku.edu.sa }}$
}

doi: $10.20964 / 2018.08 .09$

Received: 3 April 2018 / Accepted: 3 June 2018 / Published: 5 July 2018

The corrosion protection ability of waste ferrochrome slag (FeCr-slag) material was investigated. FeCr-slag has been milled for 4 hours in order to obtain nanostructured material. As a nanomaterial, this compound was used as prepared as well as a nanocomposite with polyaniline. The nanocomposites were prepared by in-situ polymerization technique. The prepared materials were characterized by FTIR, XRD and SEM. The anticorrosion performance of FeCr-slag material, polyaniline (PANI) and a nanocomposite of $\mathrm{FeCr}$-slag material with polyaniline was evaluated by incorporating these pigments in a commercial epoxy paint system. The prepared coatings were investigated for their anticorrosion ability by exposure to corrosive media in salt spray chamber as well as the electrochemical potentiodynamic polarization (PDP) and electrochemical impedance spectroscopy (EIS) methods. The results show that the nanocomposite pigments performed better, followed by FeCr-slag material and followed by PANI respectively. Modification of the FeCr-slag material with PANI has significantly improved the anticorrosion properties of the paint system used.

Keywords: carbon steel, corrosion inhibition, FeCr-slag, PANI, nanocomposites

\section{$\underline{\text { FULL TEXT }}$}

(C) 2018 The Authors. Published by ESG (www.electrochemsci.org). This article is an open access article distributed under the terms and conditions of the Creative Commons Attribution license (http://creativecommons.org/licenses/by/4.0/). 